\title{
スポーツサイクル利用増進のための 愛好家と利用者の意識分析
}

\author{
中嶋 悠人 1 ・山中 英生 $2 \cdot$ 真田 純子3 \\ 1学生会員 徳島大学 先端技術科学教育部（干770-8506 徳島県徳島市南常三島町2-1） \\ E-mail: maxyuuto@yahoo.co.jp \\ 2正会員 徳島大学教授 大学院ソシオテクノサイエンス研究部 \\ ( ₹770-8506 徳島県徳島市南常三島町2-1) \\ E-mail: yamanaka@ce.tokushima-u.ac.jp \\ 3 正会員 徳島大学助教授 大学院ソシオテクノサイエンス研究部 \\ （テ770-8506 徳島県徳島市南常三島町2-1） \\ E-mail: sanajun@ce.tokushima-u.ac.jp
}

\begin{abstract}
クロスバイク, ロードバイクなどのスポーツサイクル（以下SC) は，普及しているシティサイクルと比べ ると, 高速・長距離・長時間の走行が可能であり, 全身運動にも優れていることから, 中距離通勤や健康 活動に適している。このため, $\mathrm{SC}$ 普及・利用促進は環境・健康に配慮した都市づくりにとって，重要な 政策になるといえる.

本研究は, SC利用者の増進のための施策を検討することを目的に, SC愛好家へのヒアリング調查と物 語分析およびSC利用者への意識調查を行い, SC愛好の促進要因, 阻害要因を分析寸るとともに, 選好す る利用環境や利用促進施策への賛同を分析した。この結果，愛好要因として初期の同行型走行，挑戦心・ 達成感を得られるコース経験, などが明らかになり, SC利用増進に向けた施策の方向を提案した.
\end{abstract}

Key Words : sport bicycles, cyclist community, cycling environment, Shikoku area

\section{1. はじめに}

近年，環境問題や健康意識の高まりから自転車が注目 されている．日本では毎年販売される自転車の約 $60 \%$ を低速・短距離・短時間の走行に適したシティサイクル が占めているが，最近はロードバイクやクロスバイクと 呼ばれる SC の販売が増加している. SC は平成 15２2 年度に販売台数が約 3.8 倍になり，全体の約 $10 \%$ 占め ている ${ }^{1)}$

健康促進，ダイエット効果がある適切な運動量は，最 大心拍数の $60 \%$ 程度の心拍数で長時間(20 分以上)の運動 が必要とされるが 2)，SC はシティサイクルに比べて高 速・長距離・長時間の走行が可能で，こうした健康に資 する運動もシティサイクルより達成しやすい，健康への 配慮から通勤目的で自動車から自転車に転換する際にも SC が多く選ばれている.このように，SCの利用が促進 されるような都市政策は，環境・健康に配慮した都市づ くりにとって, 今後重要性を増すと考えられる.

本研究では，以上の背景から，SC利用者の増進のた
めの施策を検討することを目的に，SC購入者が愛好に 至った経緯，経験，走行ルートの選好を明らかにすると ともに，SC利用者の利用環境を分析し，利用環境のあ り方や情報伝達方法，人の繋がりの仕組みを提案するこ とを目標としている.

\section{2. 既存研究及び海外の取り組み}

自転車の利用意向に関して，竹腰ら゙は，自転車から 自動車，自動二輪，原付に転換する18歳から22歳までを 過渡期の年代として，自転車に対する評価の変化や自転 車の利用動向などを調査・分析している。藩(4)，大学 生の将来の自転車利用意向に与える影響について，日本， フランス, 中国, 韓国の4カ国でアンケート調査を行い, 比較分析を行い, 自転車利用意向に影響を与える要因と 将来の利用意向との関係も分析している. Hunt・ $\mathrm{Abraham}^{5}$ は自転車道のインフラ政策が自転車利用意向の 向上に与える影響を分析している.

また，自転車利用促進のための走行空間に関する研究 
として, 三輪ら けは自転車走行空間における整備効果の 定量的な分析を行っている. 山中ら 》はプローブバイシ クルを用いて，走行快適性を評価する方法を開発すると ともに，自転車利用者にとっての快適性から利用空間の 検討を行っている.

自転車利用促進の取り組みに関しては, アメリカでは, 自治体が 2000 年前後から駐輪用の自転車ロッカーの提 供と民間のフィットネスクラブなどと提携したシャワー, 衣服ロッカーの提供が行われている ${ }^{8}$. また，オランダ では, 自転車通学のためのルートとして, 学校周辺のル 一トの開拓事業を実施しているほか, インフラの整備, 交通教育, 親とのコミュニケーションなど幅広い対策を 講じるため, 学校当局, 親, 教師, 子ども自身, 近隣地 域の居住者, 警察, 自治体などと連携する総合計画を講 じている 9. 欧州では，ヨーロッパ自転車連盟がヨーロ ッパ大陸やイギリスなどの国境を越えた自転車ツーリズ ムと自転車利用促進を目指して，広域自転車ネットワー ク「ユーロベロ」を提唱し， 2020 年までに， 6 万 $6000 \mathrm{~km}$ のネットワーク整備を目指している ${ }^{10)}$.

このように，健康・環境・観光などの面から自転車利 用促進に向けた研究が見られる.これらの研究では, 海 外はSCを利用する自転車が想定されているのに対して, 我が国ではその多くが，低速のシティサイクルの利用が 前提となっており, 長距離・中速度の交通手段としての 視点に欠けている.

このため本研究では, 我が国で増加しつつある, SC 利用者に焦点をあてて, 特に愛好者の意識特性や利用者 の環境への要望を分析することで，SC 利用者を増進す るための政策に活かせる知見を得ることを目的とした.

\section{SC 愛好者へのヒアリング実施と分析方法}

$\mathrm{SC}$ 愛好者の意識や動機をヒアリングにより聴取し, 物語分析を実施した。

対象者の抽出は, 自転車店で SC 愛好者にヒアリング を行い，それから知り合いの愛好者を紹介してもらうと いう芋づる方式（雪だるま式サンプリング）で実施した. この結果 14 名にヒアリングを実施した.

このうち, 最初の 8 名は SC を愛好するようになるま での要因を把握するヒアリングを行った．それをもとに, 動機, ユーザー特性, 参加イベントなどの質問フレーム を固定して, 他の 6名について, 全フレーム項目による ヒアリングを実施した.

この 6 名の SC を愛好するに至った経緯を物語として 分析寸る. SC 愛好に至るまでの経緯を読み解き, SC 促 進要因と SC 抑制要因を読み取ることが物語分析の目的 である. 加えて, SC に乗り始めた頃, 愛好が定着して いる現在について, 走行しているルートの特性, 走行距
離を比較することで, 愛好に至る中で, 必要な環境要因 や社会的要因についても分析する.

\section{SC 愛好者の物語分析と要因分析}

\section{(1) 物語分析例}

ここでは, Aさん(39 歳 男性 スポーツサイクル歴 約 1 年 2 ケ月)を例に物語分析を紹介する.

\section{〜SC を購入するまでの段階〜}

仕事でよく東京に行く時期があった A. その頃は，東 京でスポーツサイクルに乗っている人をよく見かけたそ うだ. その頃は,

「まだスポーツサイクルを買ってないし，知識が乏しい から，ギアがあったりなかったりっていうの寸ら知らな いし，・・その知識がそしかったから，ああこれ速そう， 良さそうぐらいのイメージ。」であったという。

スポーツサイクルをほとんど知らなかったが，東京で みたスピードの速さに惹かれ，興味を持ち出すことにな った. インターネットや雑誌でスポーツサイクルに関し ていろいろ調べだした. また, 友人がスポーツサイクル を買っていたので，その友人から話を聞かせてもらった。 スポーツサイクルは「とにかく軽い力で速く進める」と 友人から聞く.A はスポーツサイクルを買いたいとおも っていたが，まだ買う決心がつかなかった。

そんな A がスポーツサイクルを買おうと決めたのは, 「一緒に買う友達が先に買って，ちょっと乗らしてもら って, おもろそう. で, この自転車屋で乗って, めっち やおもろいやん・・・買うわって感じ.」だった. 試乗でスポーツサイクルを実感したのだ.

「今まで乗ってきた自転車じやない!」「最初, 前傾や からフラフラするんやけど, 軽いし・・・普通のママチ ヤリよりも倍ぐらい軽いのにスピードがでる！！」と, 驚いていた.

\section{〜愛好が定着するまで〜}

友人の影響でスポーツサイクルを買った A は，当然 友人と一緒に走りたいと考えていた. でも，仕事の関係 上，友人と走る時間帯が合わなかったので，最初は一人 で走っていた. この頃によく走っていたのは，

「最初やっぱり，自分がどれだけ走れるか分からんから， この自転車屋を目標地点として, 平坦な吉野川沿いを走 った.」「よく吉野川南岸は車で走ってた. ランしてる 人も見かけるし, バイク乗ってる人も見かけるし, 結構 見通しもいいし，走ると.」

彼はよく吉野川沿いを通って自転車屋に行き，家に帰 るという $30 \mathrm{~km}$ 程度の道のりを走っていた. 吉野川沿い の道は平坦で楽に走ることができた．また車道を走らず 
にすんだので安全だった.

しかし，街中を走っている時には不満や不安を持って いた.「意外と路面が粗い、ロードバイクって思ったよ り速いから，車が飛び出してくるんよね。毛したら意外 と速いから近いんよ．路面が粗いから夜間とかの走行は 怖い上ね.」

しかも吉野川を走って, よく自転車屋に通っていたこ とで，サイクリング仲間ができた．Ａは，仲間に山道や お寸寸めのサイクリングコースに連れて行ってもらい, 山道を上りきったときの達成感, 開放的な景色の中を走 る気持ちよさを味わう。

\section{～愛好の定着〜}

$\mathrm{A}$ は今でもよく吉野川沿いの道を通って自転車屋に行 っている. しかも今は，そこから大坂峠を超えて瀬戸内 海側に抜けて，鳴門市北部の海岸沿いの道を通って家ま で帰るという 70km程度の道のりを走っている.

「平坦コースと山コースと二つ取れて, 景色もいいし, 途中で休憩する所もあるし，全く知らん所を走ったら不 安なんで，ある程度知ってる所を走るんや(笑)」

と語る。いろいろな山道をサイクリング仲間と走りにも 行き, 最長では $100 \mathrm{~km}$ 近く走ったこともあるそうだ. 今ではすっかりサイクリングが趣味になっている.

この物語から見える，重要なキーやイベントは，SC との出会い, 愛好家の友人, 一人走行, 吉野川, 自転車 屋, 仲間との出会い, 複数走行, 山道, 達成感のあるコ 一ス, 景色と言える.

\section{(2) SC愛好要因の分析結果}

6 名の物語分析をもとに, 愛好のきっかけ, 定着, 阻 害の要因を抽出した. さらに, 6 名の物語分析 $(\mathrm{A} \sim \mathrm{F})$ 及 びその他 8 名の内, 愛好要因の一部を質問した 5 名 (a〜 e)を加えて, SC の利用促進要因と SC の利用を抑制する 要因を探るため, 購入段階での興味をもった理由, 買う きっかけ, 定着段階での複数走行と個人走行, そして乗 り始めた頃の不安・不満要素について, 指摘の有無を整 理した結果を表-1, 表-2に示す.

\section{a) 購入段階}

SC に興味を持った理由について見ると, 健康促進(5 名), スピード感(3名), 経済的(2名), 通勤(2名), 長距離 走行(2 名)となっている. 一方, 買うと決めたきっかけ としては, 友人・知人の話(4 名), 自転車屋の話(2 名)で ある.

つまり，健康に良く，経済的で，通勤に使えるという 日常でのメリットとスピード感, 長距離走行が可能とい う認知が，興味喚起を促進する要因と考えられる．また， スポーツサイクルを利用している人からの情報, アドバ
表-1 SC の愛好要因と指摘結果 ( $\mathrm{SC}$ 購入まで)

\begin{tabular}{|c|c|c|c|c|c|c|c|c|c|c|c|}
\hline SC促進要因 & \multicolumn{7}{|c|}{ 対象者 } \\
\hline \hline 興味を持った理由 & $\mathbf{A}$ & $\mathbf{B}$ & $\mathbf{C}$ & $\mathbf{D}$ & $\mathbf{E}$ & $\mathbf{F}$ & $\mathrm{a}$ & $\mathrm{b}$ & $\mathrm{c}$ & $\mathrm{d}$ & $\mathrm{e}$ \\
\hline \hline スピード感 & $\bigcirc$ & & & & $\bigcirc$ & & & & & & $\bigcirc$ \\
\hline 健康促進 & & & $\bigcirc$ & & & $\bigcirc$ & $\bigcirc$ & $\bigcirc$ & & & $\bigcirc$ \\
\hline 経済的 & & $\bigcirc$ & & & $\bigcirc$ & & & & & & \\
\hline 通勤 & & & $\bigcirc$ & $\bigcirc$ & & & & & & & \\
\hline 長距離走行 & & & & $\bigcirc$ & & $\bigcirc$ & & & & & \\
\hline 笳力の向上 & & $\bigcirc$ & & & & & & & & & \\
\hline 環境に良い & & & & & $\bigcirc$ & & & & & & \\
\hline 山道走行 & & & & & & $\bigcirc$ & & & & & \\
\hline ファッション & & & & & & & & & $\bigcirc$ & & \\
\hline その他 & & & & & & & & & & $\bigcirc$ & \\
\hline \hline 買うと決めたきっかけ & $\mathbf{A}$ & $\mathbf{B}$ & $\mathbf{C}$ & $\mathbf{D}$ & $\mathbf{E}$ & $\mathbf{F}$ & $\mathrm{a}$ & $\mathrm{b}$ & $\mathrm{c}$ & $\mathrm{d}$ & $\mathrm{e}$ \\
\hline \hline 友人・知人の話 & & $\bigcirc$ & & & $\bigcirc$ & $\bigcirc$ & & $\bigcirc$ & & & \\
\hline 自転車屋の話 & & & $\bigcirc$ & $\bigcirc$ & & & & & & & \\
\hline 試乗 & $\bigcirc$ & & & & & & & & & & \\
\hline
\end{tabular}

表-2 SCの愛好要因と指摘結果 (SC愛好定着まで)

\begin{tabular}{|c|c|c|c|c|c|c|c|c|c|c|c|}
\hline \multirow{2}{*}{$\begin{array}{l}\text { 最初に一人で走行 } \\
\text { 又は複数人で走行 }\end{array}$} & \multicolumn{3}{|c|}{ 一人 } & \multicolumn{3}{|c|}{ 複数人 } & \multicolumn{5}{|c|}{ 未回答 } \\
\hline & \begin{tabular}{l|l|}
$\mathbf{A}$ & \\
\end{tabular} & B & $\mathrm{C}$ & D & E & $\mathbf{F}$ & $\mathrm{a}$ & $\mathrm{b}$ & $\mathrm{c}$ & d & $\mathrm{e}$ \\
\hline SC促進要因 & & & & ○ & $\mathrm{O}$ & O & & & & & \\
\hline SC抑制要因 & 0 & 0 & 0 & & & & & & & & \\
\hline \multirow{2}{*}{$\begin{array}{l}\text { SC抑制要因(乗り始め } \\
\text { た頃の不満又は不安) }\end{array}$} & \multicolumn{11}{|c|}{ 対象者 } \\
\hline & $\mathbf{A}$ & $\mathbf{B}$ & $\mathbf{C}$ & $\mathbf{D}$ & $\mathbf{E}$ & $\mathbf{F}$ & $\mathrm{a}$ & $\mathrm{b}$ & c & $\mathrm{d}$ & $\mathrm{e}$ \\
\hline 車に対する危機感 & 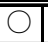 & $\overline{0}$ & & O & & & & & $\overline{0}$ & & \\
\hline 路面の悪さ & 0 & & O & & & & & & & & \\
\hline パンク & & O & & & ○ & & & & & & 0 \\
\hline マナーの悪い自転車 & & O & & & & & & & & ○ & \\
\hline 夜間走行 & 0 & & & & & & & & & & \\
\hline 下りの坂道(山) & & & & & 0 & & & & & & \\
\hline ビンディングの使用 & & & & & & O & & & & & \\
\hline 事故 & & & & & & & & & & & 0 \\
\hline
\end{tabular}

イス, 勧誘が購入には重要な要因と考えられる.

\section{b) 愛好の定着段階}

6 名の内には，最初に走り始めたころ，一人で走行し ていた人が 3 名, 複数で走行していた人が 3 名であった 複数人であった全員が良かったとして, 逆に一人走行者 は全員良くなかったとしている．この質問は a e には 質問されていない. これより, スポーツサイクル初心者 には, サイクリング仲間の存在が共通する定着化への促 進要因と考えられる.

\section{c) 定着期の阻害要因}

乗り始めた頃の不安又は不満として，車に対する危機 感(4 名), パンク(3 名), 路面の悪さ(2 名), マナーの悪い 自転車(2 名)を指摘している。これらからみると, 走行 ルートの環境の悪さと走行時に見舞われるトラブルが共 通した定着への抑制要因と言える.

\section{(3) 走行距離・走行ルートの変化に関する分析結果}

図-1 は 6 名の分析対象者 $(\mathrm{A} \sim \mathrm{F})$ にいて, 1 日で走る ときの走行距離をスポーツサイクルに乗り始めた頃と現 在で比較したものである. 全員, スポーツサイクルに乗 り始めた頃に比べて, 現在の走行距離は $25 \mathrm{~km} \sim 80 \mathrm{~km}$ 増 えている. 


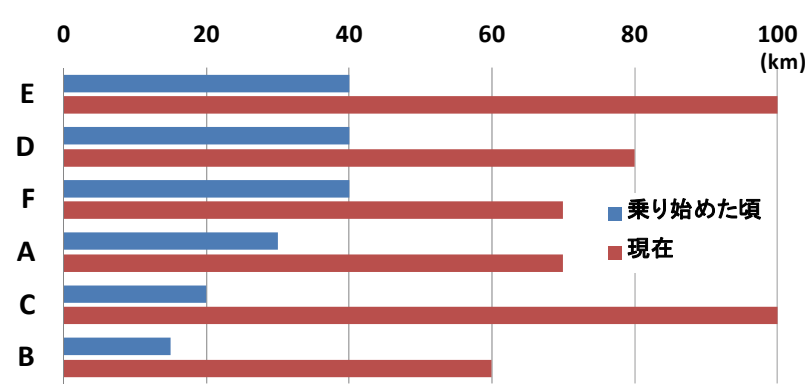

図-1 愛好定着後の 1 日走行時の走行距離の変化

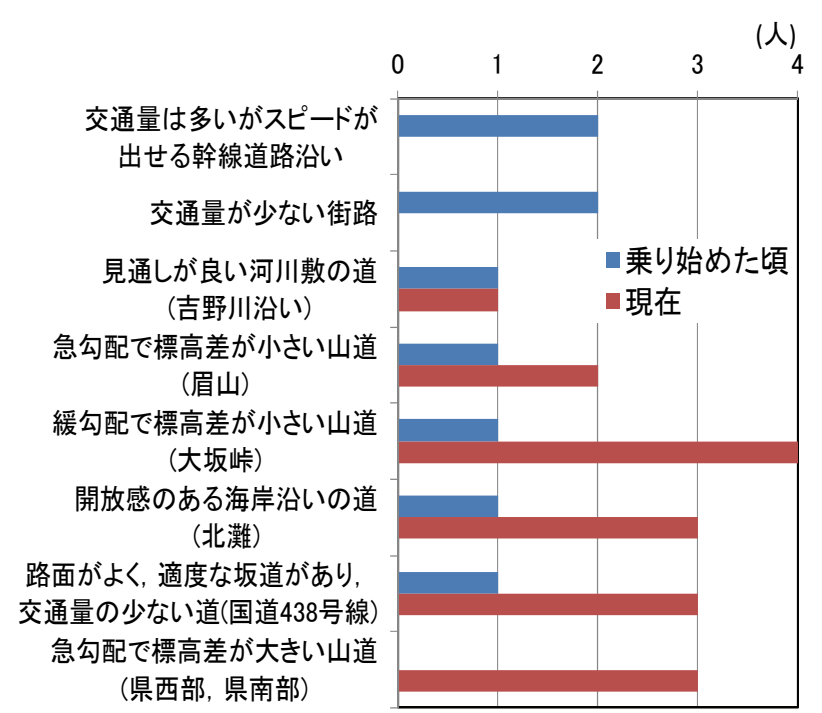

図-2 愛好定着後の走行ルートの変化

図-2 は分析対象者 $(\mathrm{A} \sim \mathrm{F})$ の走行しているコースを，ス ポーツサイクルに乗り始めた頃と現在で比較した結果で ある．乗り始めの頃は，「交通量は多いがスピードが出 せる幹線道路沿い」と「交通量が少ない街道」の割合が 高いが，定着後は，「勾配が緩やかで標高差が小さい山 道」，「開けた景色が見える海沿いの道」，「路面が良 く, 適度なアップダウンがあり, 交通量の少ない道」,

「勾配がきつく標高差が大きい山道」などの割合が高く なっており，最初は平坦でスピードが出せる道が好まれ るが，趣味として定着後は，むしろ勾配が存在する山道 を好んで走っている. SC の愛好が定着する過程で，ス キルの上達とともに，難コースへの挑戦心や，達成感を 味わう喜びが重要な要素となっていることがうかがえる.

\section{SC 利用者の意識調査の概要}

次に，一般的な SC 利用者に対して，利用経緯，走行 ルート，SC利用増進政策に対する意識を分析した。

対象者は公道走行をするためのスポーツタイプ自転車 利用が定着している者を抽出するため，ロードバイク又 はクロスバイクを購入して，1 年以上利用している条件 でスクリーニングを行った. 楽天リサーチ社の WEB ア ンケート調査で，対象地域は四国県内として，合計 200

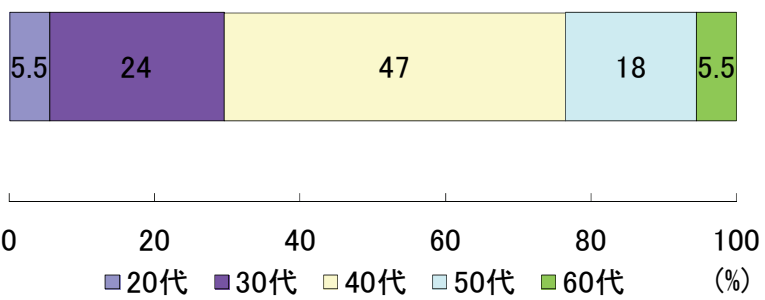

図-3 年齢構成

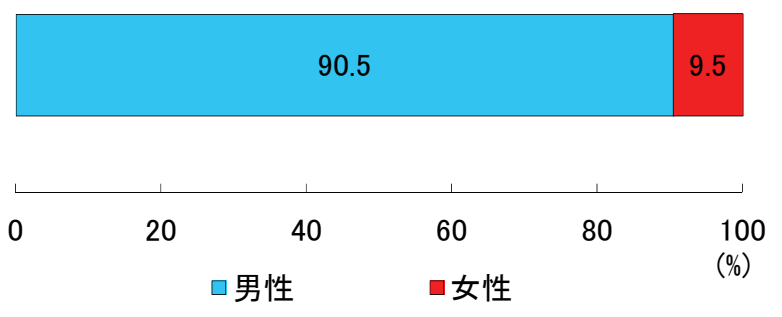

図-4 性別構成

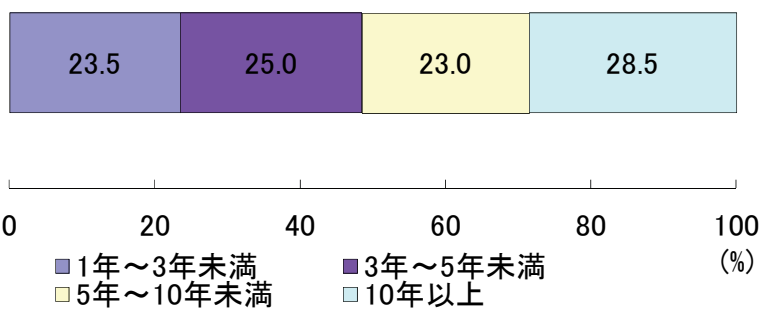

図-5 SC 経験年数

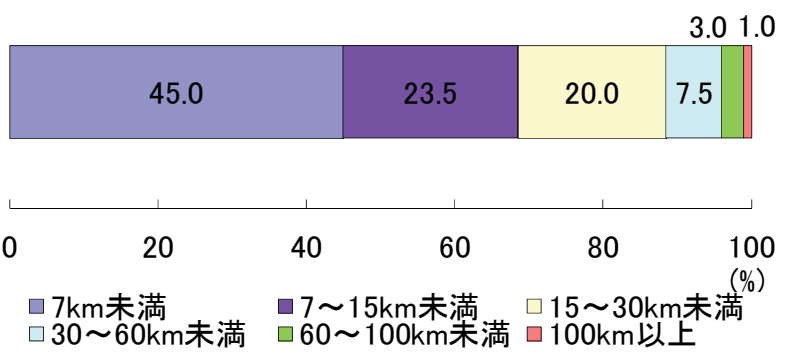

図-6 現在の 1 日走行時の走行距離

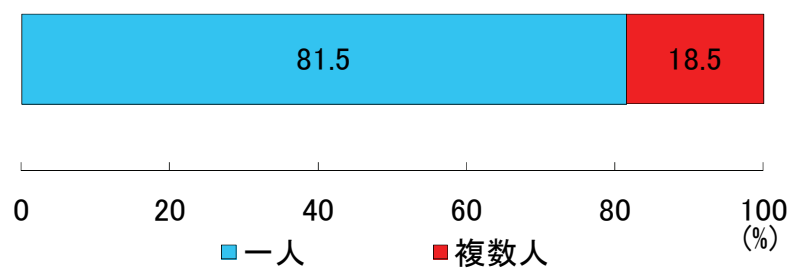

図-7 走り始めた時の走行人数

サンプルを収集した。

図-3，4，5 にサンプル属性を示す．40 代のユーザー が多く，20 代，60 代のユーザーが少ない。また，男性 が 9 割以上占め，女性が 1 割未満であることが確認でき る. SC 経験が 10 年以上のユーザーが多くなっている.

図-6 は，1 日走行時の走行距離を示している. これよ りユーザーのレベルとして，7km 未満(90人)をローユー ザー， $7 \mathrm{~km} \sim 30 \mathrm{~km}$ 未満 (87 人)をミドルユーザー， $30 \mathrm{~km}$ 
以上(23人)をハイユーザーに区分した.

図-7 は，SC で走り始めた時に走行していた人数であ る. 8 割が単独で走行しはじめており，走行ペースをあ わせられる同行者が不在などのため, 多くは単独となっ ていることが伺われる. 同行者と一緒に走行している 20\%は走行マナ一や走行ルートなどに異なった経緯をも つと考えられる。 そこで，SC 初期に一人で走行してい たユーザー(137 人)を単独型, 複数で走行していたユー ザー(37人)を同行型として区分した.

\section{SC 利用者の意識分析結果}

以下では，一日走行時の走行距離によるハイ，ミドル， ローのユーザーレベル，走行し始めた時期の同行者の区 分別に意識の違いに着目した。

\section{(1) SCに興味をもったきっかけ}

図-8，9はSCに興味を持ったきっかけについてユーザ ーレベル別と同行有無別に集計した結果を示している.

全レベルに共通して「健康への配慮」が高くなってい る.ただし，ローユーザーは通勤利用にしたいきっかけ が他より多く，ミドルユーザーはスピード感への感心の 割合が高くなっている。 これに対して，ハイユーザーは ツーリングへの興味の割合が高い、移動手段の興味をも ったローユーザーに対して，ミドル・ハイユーザーは楽 しむためのSCとして興味をもっていたことがわかる.

同行型と単独型の比較でみると，初期段階から同行者 のいた人は「SCでのツーリング」に興味をもっていた 割合が高くなっている. ツーリングを楽しみとするユー ザーは最初から同行者に指導を受ける要素が重要である と言える.

\section{(2) 走り始めた時の不満・不安}

図-10は，走り始めた時の不満，不安を同行有無別に 集計した結果である。「路面の粗さ」，「事故・パン ク」に対する不満，不安が同行有無に関係なく高い．特 に単独型の場合に路面, パンク, マナ一の悪い自転車と いった不安の指摘が高くなっている.

\section{(3) 走行ルート変化}

調査では，SCで走り始めた時に好んで走行していた ルート，現在好んで走っているルートを選択させている. このデータをもとに, ルート特性ごとに, 現在走行して いるが初期は走行していなかったユーザーの割合 (増加 率) と， SC初期は走行していたが現在は走行していない ユーザーの割合 (減少率) を求めて, その差 (純増率) を算出した. 図-11はユーザーレベル別に上記の純増率 を求めた結果を示している.

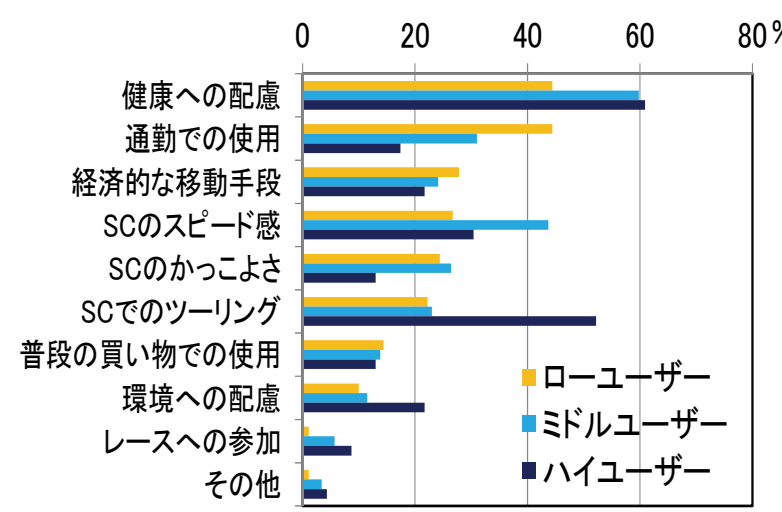

図-8ＳCCに興味を持ったきっかけ（ユーザーレベル別）

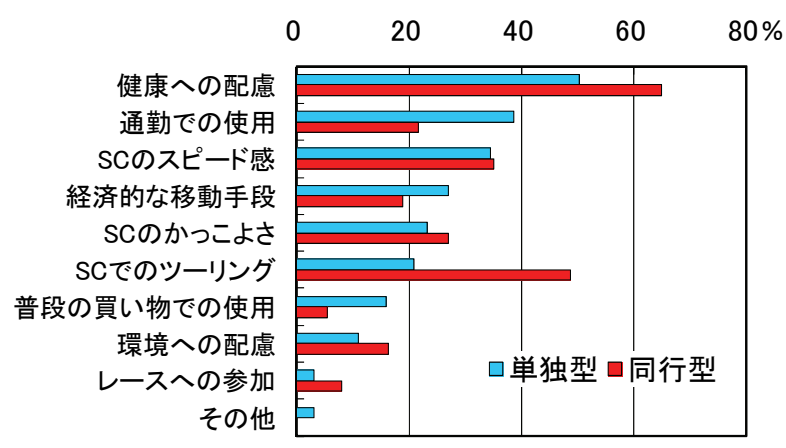

図-9 SCに興味を持ったきっかけ(単独型・同行型)

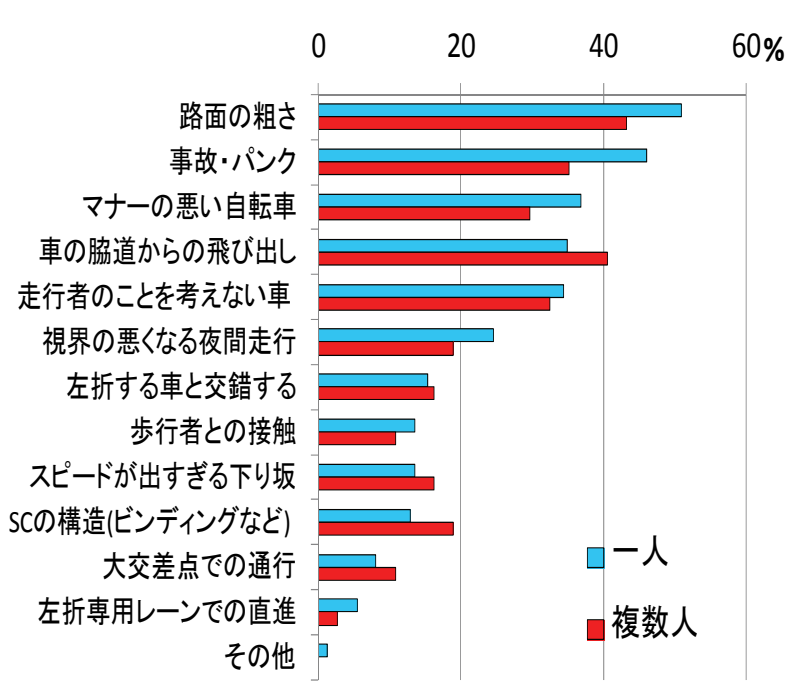

図-10 SC初期における走行中の不安，不満(単独型・同行型)

これらより，ロー，ミドルユーザーでは純増率は大き くなく，利用ルートの変化が少ないことがわかる．また， ローユーザーは「平坦な道」，「歴史のある道」，「交 通量の少ない道」などの純増がみられる. このようにロ 一ユーザーは，安全で負荷の少ない道を走行し，日常の 移動手段や通勤に使用しており，そうしたルートを利用 し続ける傾向がある. 


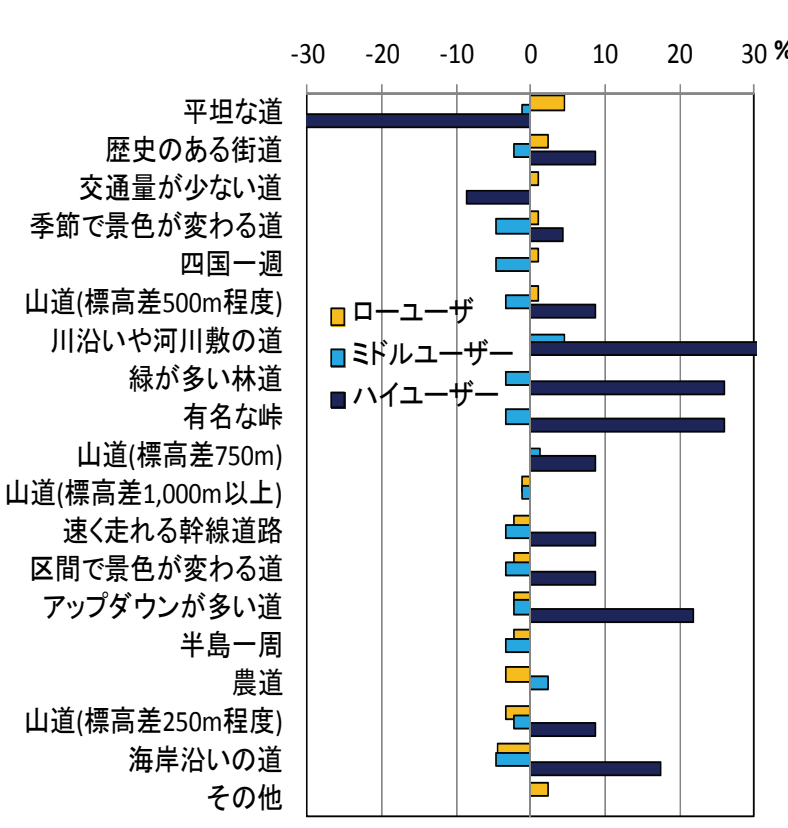

図-11初期と現在のルート变化(ユーザーレベル別)

ミドルユーザーでも，変化量は大きくはないが，多く のルートで純増率が負となっており，「川沿いや河川敷 の道」，「農道」のみが純増している．ミドルユーザー は，始めは多様なコースを走っているが，時間が経過す るにつれて，好むコースが限定されてきていると考えら れる.

一方で，ハイユーザーは平坦な道，交通量の少ない道 を減らしているが，他の多様なルートの利用を増加させ ている. 特に，「川沿いや河川敷の道」，「緑が多い林 道」,「有名な峠」,「アップダウンが多い道」などで 純増率が大きくなっている，ハイユーザーは，単調・安 全な道よりも，開放感や爽快感のある気持ちの良いサイ クリングコースや達成感や充実感を味わえるような負荷 の高いサイクリングコースを好むようになっていること がわかる。

\section{（4）利用増進策に対する賛同率}

図-12はSC利用者を増進するための施策に対する賛同 率をユーザー区分別に整理した結果である.

全てのユーザーが「サイクリング専用道を河川敷に作 る」の割合が高く, 安全なサイクリング専用道の必要性 を考えている.

しかし，ユーザー区分によっていくつかの施策に対す る賛同率が異なる傾向が見られる.

ローユーザーは「SC 宣伝を増やして認知度を上げ る」，「SC を試乗できるレンタサイクルを作る」の割 合が高く, SC のメリットや利便性の宣伝, SC のレンタ サイクルといった体験型の情報提供が必要であると考え ていることが分かる.

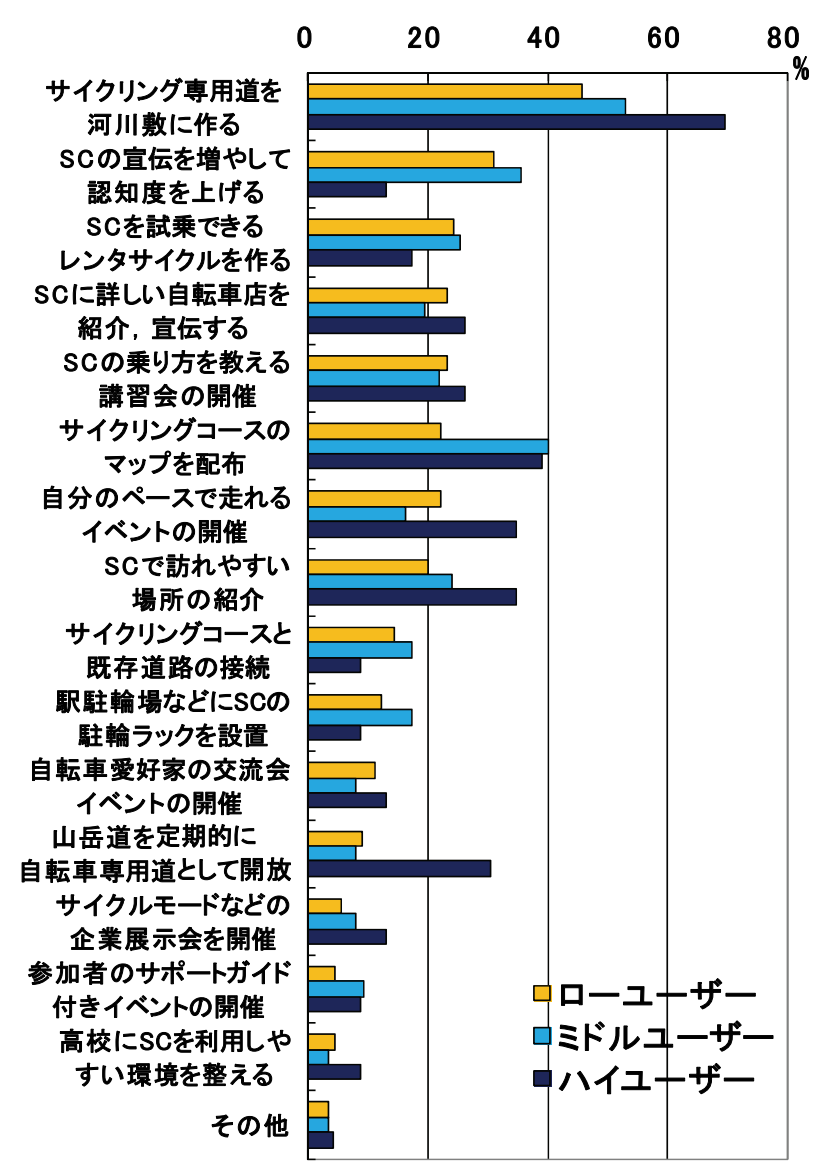

図-12 SC 利用増進策に対する賛同率(ユーザーレベル別)

ミドルユーザーは SC の宣伝に加えて，「サイクリン グコースのマップを配布」の割合が高く, サイクリング 環境の存在をユーザーに知らせる必要があると考えてい ることが分かる.

ハイユーザーは「自分のペースで走れるイベントの開 催」や「山岳道を定期的に自転車専用道として開放」の 割合が高く, サイクリング環境を創り出すことが必要で あると考えていることが分かる.

また図-13 は SC 利用増進施策に対する賛同率を同行 有無別に整理した結果である.

単独型の人は同行型に比べて「駅駐車場などに SC 駐 輪ラックを設置」が高く, 普段の生活における SC の利 用環境改善が必要だと考えていることが分かる．また， 同行型は「自転車愛好家の交流会イベントの開催」が高 く, 既存ユーザーとつながりを持つことで, サイクリン グ仲間を作ることが必要であると考えていることが分か る.

\section{7. おわりに}

愛好家のヒアリングから, スピード感, 健康促進が興 味のきっかけとなり, 友人・知人の話を購入きっかけで ある回答が多く, SC初期に複数人で走行していたこと 


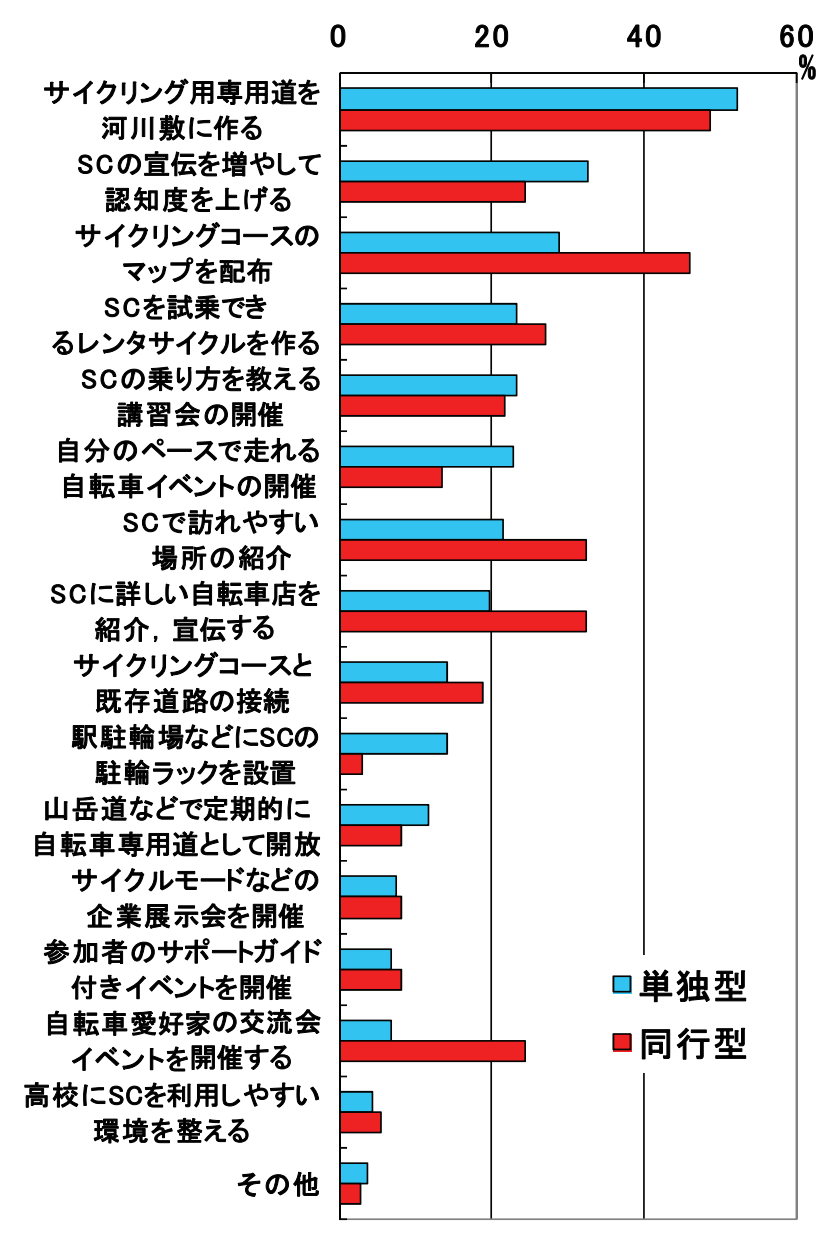

図-13 SC利用増進策に対寸る賛同率（単独・同行型別）
高く支持している， SC 認知度の向上，サイクリングコ 一スマップ配布，コースと既存道路との接続，駐輪ラッ クなどの施策や，ハイユーザーが支持するような，山岳 道を定期的に自転車専用道として開放，同行型ユーザー が支持している自転車愛好家の交流会イベントの開催な どが着目される.

以上の考察を合わせ，愛好度の高い SC 利用者を増進 する施策として以下の 3 点を提案する.

1) 初期段階で単独走行になりやすい愛好者をつなげる コミュニティの形成. これには SC を販売する自転車店 の活用に加えて，イベントやサイクリング拠点整備の取 り組みが考えられる.

2） SC 利用環境の見える化と認知向上. これには，コー スマップ整備, 多様な店舗での SC ラック設置などの施 策が考えられる.

3) 挑戦心や達成感を得られるサイクリングコース. 都 市部から安全にかつアクセスしやすい環境下にこうした コースが存在していることが，SC の愛好度を高める都 市環境として重要と考えられる.

今後は, 埼玉県, 奈良県, 愛媛県など先進的なSCを 利用したサイクリング・観光戦略を実施している事例の 分析とともに，愛好家が利用するコースの道路交通環境 や魅力的なサイクリングイベント要素, SC愛好家の自 転車走行ルール・マナ一の推進における効果検証を分析 していきたいと考えている.

\section{参考文献}

1) 自転車産業振興協会：国内販売動向調査 平成 15 年 22 年度

2) 絹代 : 自転車でカラダとココロのシェイプアップ, pp.74-75, 140-141, 枻出版社, 2008.

3) 竹腰祥紀, 古池弘隆, 森本章倫 : 自転車から自動車 への利用転換期における移行要因に関する研究, 土 木計画学研究・論文集, No.19, pp.415-421, 2002.

4) 藩哲: 自転車利用の状況, イメージと将来利用意向 の関係に関寸る国際比較意識分析, 徳島大学博士論 文, pp.1-118，2011。

5) Hunt and Abraham: Influences on bicycle use, Transportation, Vol.34, pp.453-470, 2007.

6) 三輪富生, 山本俊行, 森川高行 : 名古屋市における 自転車走行空間の利用意向調査と整備効果の分析, 都市計画論文集, Vol.46, pp.793-798， 2011.

7) 山中英生, 土岐源水, 二神彩, 亀谷一洋 : プローブ バイシクルを用いた自転車利用環境の評価, 土木計 画学研究・講演集, Vol.26, 2002.

8) 吉倉宗治：成功する自転車まちづくり 政策と計画 のポイント, pp.65-66, 学芸出版社, 2010 .

9) 前掲 8), p.88

10) 前掲 8), pp.112-113

(2013. 2. 25 受付) 


\section{AN ANALYSIS OF CONSCIOUSNESS OF AVID CYCLISTS AND SPORTS BICYCLE USERS FOR FORMING THEIR PROMOTION SCHEMES}

\section{Yuto NAKASHIMA, Hideo YAMANAKA and Junko SANADA}

Sports Bicycles have an advantage for promote long distance commuting and activity for health because higher speed, longer drives can be achieved, comparing with city bicycles which are used widely in Japan. For this reason, it would be important to spread and promote sport type bicycles for the purpose of creation of environmental and healthful cities.

This study aims at proposing promotion schemes for sports bicycles by employing narrative analysis of avid cyclists and internet questionnaire survey of sports bicycle users, focusing on their promoting and inhibiting factors, favor on road environment and attitudes to promoting schemes. Consequently, it found as promoting factor, for example, exist of accompanying person for beginners, experience of cycling which can feel challenge and accomplishment sprits. On the basis of these results, the authors proposed some promotion schemes. 